\title{
Tracking the Indigenous Sacred, Chidester-style
}

\author{
Rosalind I.J. Hackett \\ rhackett@utk.edu
}

\section{Abstract}

The article evaluates David Chidester's Wild religion (2012) for what it teaches us about tracking and studying the 'indigenous sacred' in contemporary South Africa, and, by extension, in Africa more generally, and the diaspora. By adopting a more dynamic and open-ended approach to religion as a set of resources and strategies, Chidester provides critical insights on the production, appropriation, and interpretation of indigenous religious myths and rituals in the post-apartheid setting.

Keywords: indigeneity, traditional religion, South Africa, symbols, heritage, dreams, media, education, politics, methodology

Despite the richness and complexity of the David Chidester oeuvre, I had no hesitation in deciding on my focus for this special issue. I wanted to celebrate one of Chidester's later works, Wild religion: Tracking the sacred in South Africa (Chidester 2012) that, in my estimation, deserves wider readership. Many colleagues of mine, whether Africanist or not, know Savage systems: Colonialism and comparative religion in Southern Africa (Chidester 1996) to be a landmark text, but not so many have tackled Wild religion. Perhaps they were turned off by the quirky title (as I was initially, but then remembered that adage about books and covers) or did not encounter the type of advocate that Charles Long was for Savage systems. So, my role here as 'cheerleader' is to assess the book for what it teaches us about tracking the 'indigenous sacred' in 
contemporary South Africa, and, by extension, in Africa and the diaspora. My primary reason for choosing this adventurous work is linked to the fact that I find myself in a phase of scholarly re-engagement with indigenous and traditional forms of religious belief and practice, thanks to being a core member of the Indigenous Religion(s): Local Grounds, Global Networks (INREL) project at the University of Tromso/The Arctic University of Norway (UiT n.d.). Additionally, because of my longstanding interest in the regulation of minority religious groups in the African context, the recognition, or lack thereof, of African indigenous religions is very much on my radar these days (Hackett 2015). Finally, the politics of African religious studies these days is not favoring research and teaching on indigenous religions, due to the increasing dominance of Christianity and Islam in most African national settings, let alone the conservative religious impulses that frame traditional religious heritage as, at best, irrelevant, or, at worst, 'satanic'. Perhaps Chidester's insightful analysis of the salience of indigenous religious worlds as they articulate with different aspects of contemporary South African society may direct fresh attention to the transformations of the religious dimension of African social and political life more generally.

While Savage systems and Wild religion deal with different periods of South Africa's history - the $19^{\text {th }}$-century colonial frontier and the postapartheid state respectively - they both treat religion and religious diversity from a relational and intercultural perspective, with strong emphasis on the production, appropriation, and interpretation of religious myths and rituals in the South African context. The later book, Wild religion, under discussion here, tracks the sacred in contemporary South Africa from the advent of democracy in 1994 to the euphoria of the Football World Cup in 2010 (Chidester 2012:viii). From the outset, Chidester stresses that his primary objective is to explore the 'wild, surprising creativity' of indigenous religion as it moves 'between rural and urban spaces to produce a migrating sacred, finding a home in the city by creating a hybrid sacred and assuming national significance' (Chidester 2012:ix). By the same token, he offers an exploration of religious diversity in post-apartheid South Africa, adopting an approach to religion that is not predicated on religious communities and institutions, but rather one that treats religion as 'an open set of resources and strategies for negotiating a human identity, which is poised between the more than human and the less than human, in the struggles to work out the terms and conditions for living in a human place oriented in sacred space and time" (Chidester 2012:ix). This 
generative definition justifies his focus on the dynamics of the 'sacred' (his preferred operative term) and its production in the now globalizing conditions of the country he has inhabited since the 1980s. It also opens the door for him to consider how 'wild religion' can be regarded as good (heritage and dreams), bad (wild space, violence or terror) or ugly/messy (sex, sovereignty, and festival) (Chidester 2012:5), in ways that are 'all mixed up', as in the case of religious tourism that has the potential for new forms of religious engagement, but also desecration (Chidester 2012:ix-x). To boot, Chidester wants to challenge the national narrative of oppression and liberation by facilitating the emergence of different stories about religion and society in South Africa.

It is to some of these stories that we now turn to understand Chidester's central thesis that the sacred is produced in relation to wild forces. He explains this as follows: 'Sacred space and time, sacred roles, rituals, and objects, are created by both excluding and incorporating the wild. This dual dynamics of the sacred, excluding and incorporating, exorcising and domesticating, is inherent in the duality of the wild' (Chidester 2012:2).

Thus, the wild presents an obstacle to maintaining, as well as energy for creating sacralized social order (Chidester 2012:3). I have chosen to concentrate on select chapters that are particularly instructive for appreciating Chidester's analytical insights, as well as their value for stimulating new and arguably more relevant approaches to the study of indigenous and traditional religions in Southern Africa and beyond. Reluctantly eschewing his wild tour of the Cape Town religious scene in chapter two ('Mapping the sacred'), the imbrications of South Africa's violent history with religious positions in chapter three ('Violence'), his review of the encroachment and negative impact of religious fundamentalisms in South Africa since the 1970s in chapter four ('Religious fundamentalisms'), the controversy over the then president, Jacob Zuma's fathering of a child outside of his traditional polygamous marriage and his recourse to religious (Zulu traditional and evangelical Christian) and political (modern constitutional rights) legitimation in chapter seven ('Purity'), and chapter nine ('World Cup') on the local, wild rituals (in 2010) of the religion of global football, I will concentrate on chapters five ('Heritage'), six ('Dreamscapes'), eight ('Power'), and ten ('Staying wild').

Chidester begins his fifth chapter on heritage by discussing the development of South Africa's National Policy on Religion and Education in 2003, which, in contrast to the Christian indoctrination of the apartheid regime, affirmed the importance of educational engagement with religious diversity 
(Chidester 2012:92-93). He alludes to his own involvement in the process of policy development and the opportunities for religion studies in the development of new forms of national, cultural, and global citizenship as part of post-apartheid nation-building initiatives ${ }^{1}$. He explains how this new policy related to former South African President, Thabo Mbeki's plan for cultural rebirth, an African Renaissance, along with moral regeneration and economic growth. Chidester explains how the new national coat of arms, that uses visual imagery drawn from Bushman rock art and a national motto of Unity in Diversity written in the extinct language of the /Xam Bushmen, was intended to signal a transformation of space and time and symbolize both African and universal truths. This evocation of the distant past means 'bringing the dead back to life', as 'these national symbols were formulated in the extinct language of an extinct people', namely the Khoisan people who were victims of colonial genocide (Chidester 2012:99). Chidester further observes how the new national symbols were posited by President Mbeki as 'natural' in that they served 'to revitalize an indigenous harmony between human beings and the environment' (Chidester 2012:100), 'ancestral' for they drew South Africans back to the precolonial era when people built their life on the 'enduring relationship between the living and their ancestors' (Chidester 2012:100), and 'universal' in that the birth of South Africa was linked with the evolutionary origin of all human beings.

In addition to considering how national symbols evoke an ancestral imaginary, Chidester looks at the new heritage sites consecrated by the postapartheid state. He contends that in renegotiating their relations with the past, both the state and the market are 'dealing in the sacred' (Chidester 2012:101). Astutely combining Durkheim's definition of the sacred as that which is 'set apart' and Régis Debray's claim that a nation is 'made out of sacred stuff' (Chidester 2012:101), Chidester adds that 'we must also recognize the ways in which the sacred is "set apart" at the center of social relations, providing highly charged terms for both social cohesion and social conflict' (Chidester 2012:101), and that this is a critical element of 'the political economy of the sacred in nation building' (Chidester 2012:101). The large-scale project known as Freedom Park is particularly interesting to Chidester as it 'was built out of nothing, a new development on vacant land, carefully constructed to draw

\footnotetext{
1 'Religion studies' is the preferred term for the academic, non-confessional approach in the South African context.
} 
sacred resources into a monumental, memorial, and ritual complex' (Chidester 2012:103). As with the national policy for religion and education, this heritage project links the present to a distant past and an open future. The myth of origin (Southern Africa's 3.6 billion years of history) informed the park's dedication to 'memorializing all who had sacrificed their lives in the struggle for humanity and freedom' (Chidester 2012:103). Chidester explains that the pile of stones from around the country at the shrine (Isivivane) in the center of Freedom Park was reminiscent of the use of stones in Southern African rituals of transition, when someone might add a stone to a pile at the start of a journey or on return. However, as an ambitious nation-building project, Freedom Park was constructed to exercise centripetal and centrifugal force, to draw in the entire nation and even the diaspora, as well as to sponsor and dispatch 'interreligious delegations to all of the provinces and neighboring countries of South Africa to perform rituals of cleansing, healing, and reconciliation' (Chidester 2012:104).

Tourism has also served to market heritage, using indigenous cultural villages revived from the apartheid era or freshly created for the 'rainbow nation' of the new South Africa, such as the Rainbow Cultural Village (Chidester 2012:104). Casinos and corporations also mobilized new resources for heritage development, in the form of advertising and theme parks. Chidester argues that these initiatives and the revised policy for religion and education were part of a new 'public pedagogy of national heritage' that celebrated 'linguistic, cultural, and religious diversity while forging national unity', as well as more inclusive forms of South African citizenship (Chidester 2012:107). He addresses the criticisms levelled at this new public pedagogy, identifying two main problems, namely creating an artificial, imaginary uniformity and focusing on 'extraordinary events of heroism, sacrifice, and loss' (Chidester 2012:108). He sounds a warning note for those working on religion education in schools, lest 'creative and critical thinking about the multiplicity of religious identities and the negotiation of religious differences...be subsumed in the artificial manufacture of consensus' (Chidester 2012:108). As for the privileging of the extraordinary, Chidester underscores the importance of balancing this with attention to everyday places and events that may be even more effective in citizenship education. Religion education, especially, needs to resist a 'world religions' model that teaches that all religions are constituted by extraordinary revelations or hierophanies, and recorded in extraordinary texts. For our purposes, he opines that this 
privileging of the extraordinary not only distorts the character of religious life, but 'it has forcefully excluded indigenous religious forms of life from the world of religions' (Chidester 2012:109). Given that such a model of world religions no longer obtains in the history of religions or religion education, he remains hopeful that teaching and learning about religion and religions will remain grounded in the 'ordinary' (Chidester 2012:109).

However, in chapter six, entitled 'Dreamscapes', we travel into what may be unexpected and not very ordinary realms for the student of African indigenous religions. Benefitting from his extensive knowledge of the South African indigenous religious scene, David Chidester leads us into the Zulu dreamscape that has been expanded and transformed by electronic media. Under these globalizing conditions, he informs us that global claims are being made on Zulu dreams just as indigenous Zulu dreams are going global ${ }^{2}$. These transformations of African indigenous religion are exemplified by the Zulu witch doctor, sangoma, sanusi, and now shaman, Credo Mutwa, who, according to Chidester, 'has emerged in the global circuit of neoshamanism as the ultimate spokesman for African indigenous authenticity', underwriting a range of projects associated with New Age spirituality, alternative healing, and encounters with aliens from outer space (Chidester 2012:113; cf. also Chidester 2002, 2008). Lest we are tempted to view a modern-day interest in Zulu dreams and dreaming through film, video, and musical CDs and DVDs as a departure from traditional African divination and dream life, Chidester perceptively reminds us that in these new media, 'we can find echoes of the nineteenth-century Zulu energetics of dreams that was based on sacrificial exchange and ancestral orientation' (Chidester 2012:113-114).

The new dispensation of the global economy brings both perils and possibilities, and Chidester discusses how Credo Mutwa has dealt with them by 'identifying aliens from outer space as the nexus of a sacrificial exchange into which he personally has entered by eating extraterrestrial beings in a sacrificial meal and by being their sacrificial victim' (Chidester 2012:114). In addition to recounting these experiences in his various books, notably Song of the stars: The lore of a Zulu shaman (Chidester 1996), Mutwa has also found a home on the internet, boosting his credibility, just as some New Age

2 For similar trends, see Douglas Falen's work on the reinvention of vodun, notably in relation to preoccupations with witchcraft in the contemporary Benin Republic (Falen 2018a, 2018b). 
enthusiasts in the West, including some of South African origin, were also availing themselves of the global network of neoshamanism and coming home to Africa by entering the 'house of dreams' as a Zulu shaman. In what follows, Chidester provides an engaging account of some of the leading Euro-American white shamans, such as David Cumes, Ann Mortifee, James Hall, and David Icke, who represent, in his estimation, an emerging trend in which these shamans turn to 'African traditions as a source of authentic dreams, visions, and connections' (Chidester 2012:120). Chidester takes our understanding of such trends to a higher level by analyzing Zulu neoshamanism as material religion, addressing the role of the human sensorium and electronic media. By approaching Zulu dreams as embodied, sensory media and as material productions, he can explore how 'indigenous sensory repertoires for arranging (and deranging) the human sensorium merge with the limits (and potential) of electronic media' (Chidester 2012:115).

As exemplified in the case of Credo Mutwa, who is known internationally as the keeper of Zulu tradition and a source of purer, indigenous African authority, while locally he is often termed a fake or a charlatan, questions of authenticity understandably matter in what Chidester describes as the 'imaginative terrain that has opened between global exchanges and local homecomings' (Chidester 2012:115). He identifies three ways of dealing with senses and media that represent registers of authenticity. The first way approaches the human senses as limiting and inadequate. Similarly, electronic media can be inimical to awareness. Credo Mutwa advises avoidance of electronic media because their inaudible sounds can block the psychic powers of aspiring sangomas. For that reason, he recommends rural areas for developing extrasensory perceptions. The second way considers the senses and media as having potential for extraordinary perception, as described by Mutwa after he claimed he ate the meat of an extraterrestrial or in James Hall's account of his synesthetic experience of visceral percussion, sound, and sight (Chidester 2012:126). The third way treats the senses as validation for shamanic initiations, and electronic media as 'metaphors for spiritual perception', as well as 'enduring forms for transmitting indigenous spiritual wisdom' (Chidester 2012:127). Mutwa even claims that the content of some Hollywood films serves to validate ancient Zulu tradition. In closing this (academic) mind-altering chapter on 'sensory extravagance' in a modern-day Zulu religion, Chidester offers an excellent summation, '[a]s both dreamscape 
and mediascape, Zulu neoshamanism is emerging within a new energetics of global exchange and global orientation' (Chidester 2012:131).

In searching for the sacred in contemporary South Africa, notably the 'recovery of indigenous religion', Chidester's eighth chapter ('Power') turns to the question of political leadership. As in the previous chapter, his account is anchored in the story of a protagonist. In this instance, it is Mathole Motshekga, a leading lawyer, politician, and proponent for recovering the integrity of indigenous African traditions of religion, culture, and identity. Born a Lobedu, the ethnic group associated with the realm of Modjaji, the rain queen, he began studying the esoteric traditions of hermeticism in Germany in the 1980s and was subsequently influenced by Afrocentric philosophers who looked to ancient Egypt as their starting point. As observed by Chidester, Motshekga has positioned himself between 'modern politics and traditional royalty' in South Africa's emerging democracy (Chidester 2012:155), serving as chief whip of the governing party, the ANC, and as legal advisor to the Royal Council of the rain queen. Motshekga's efforts to restore African traditional leadership, history, and spirituality have taken shape through the Kara Heritage Institute that he founded and continues to direct (Kara Heritage Institute 2018). Chidester helps us understand the entanglements of Motshekga's religious and political journeys and how this leading spokesperson for South African indigenous religion has used both media and political channels to advance his message that African religion, with its ancient Egyptian origin, is both the 'shared heritage and common spirituality of all Africans in the region' and the 'religious foundation for a new South Africa' (Chidester 2012:155). Chidester draws out two new emphases of Motshekga's public presentations, namely the theosophy of his heritage, which begins with an ancient Egyptian cosmogony, through an exposition of the zodiac of the heavens and the sacred calendar of festivals on earth, and ends with an account of an African personality that is believed to be divine but in 'need of recovery through the practice of the reciprocal African ethics of ubuntu and the performance of indigenous rituals of yoga' (Chidester 2012:155). In addition to this new attention to selfknowledge, Motshekga talks of the theocracy of this heritage and the need to recover and revitalize divine kingship in Africa.

Chidester muses over how such religious claims can operate within a democratic polity and identifies three different possibilities in Motshekga's advocacy - theocracy, democratic pluralism, and civil religion. He regards Motshekga's commitment to theocracy as surprising given the latter's roles in 
a democratically elected government, but understandable given his theosophical insights and interests as legal advisor to the Royal Council of the rain queen during a trying time of transition. Moreover, Motshekga will have to position his theosophically oriented African indigenous religion in a religiously diverse society, which may be challenging, in Chidester's estimation, given that Motshekga's understanding of ancient Egyptian theosophy requires a divine kingship, merging religion, and politics.

Chidester also wonders if Motshekga, in seeking to mediate between theocracy and democracy, might be trying to develop a new civil religion for South Africa. Chidester, however, flags the tensions between a religion that is premised on secret wisdom traditions from ancient Egypt, via hermeticism, rosicrucianism, freemasonry, and theosophy in Europe, and a 'civil religion' that is also supposed to function as a shared religious orientation in a democratic dispensation. Chidester spares no effort in tracing the roots of Motshekga's interpretation of ancient Egyptian religion, its links with 'white African' and neoshamanic appropriation of indigenous spirituality, its goddess orientation and claims of spiritual mastery and mediumship, along with other Afrocentric initiatives. He alerts us to the controversies surrounding Motshekga and the transmission of his theocratic tradition in a capitalist economy. Citing the work of Jean and John Comaroff (2009) on ethnic entrepreneurship in a market-driven economy, he notes that Motshekga celebrates these new possibilities, believing that exploiting ethnicity is critical for economic development, especially if 'ethnicity can be linked to divinity' (Chidester 2012:167). However, Chidester also records how Motshekga has angered other religious communities in various ways, not least by calling on all South Africans to observe the African sacred calendar with its origin in ancient Egypt, when even other contemporary leaders of African religion do not share his religious orientation. Chidester also sees the risk of Motshekga's civil religion taking on the guise of a religious nationalism, that, with his political role, might 'serve to sacralize the prevailing government as it has sacralized divine kingship' (Chidester 2012:174). Recalling the work of Robert Bellah by way of conclusion, Chidester contends that 'a civil religion, in any form, requires an aura of authenticity for its collection of symbols, beliefs, and rituals to be incorporated in a social collectivity' (Chidester 2012:175).

Arriving at his final chapter, Chidester is keen to remind us that in the 'wild and indeterminate terms of the colonial encounter, both Christian religion in Africa and African indigenous religion were made' (Chidester 2012:191). 
Religion was both a 'mark of difference separating the civilized from the wild' and 'a wild arena in which new forms of the sacred were being produced' (Chidester 2012:191). Rather than representing African indigenous religion as a stable religious system or perennial spiritual mentality as John Mbiti and others have been wont to do, Chidester prefers to characterize African religion as 'an open set of resources and strategies for sacralizing' (Chidester 2012:192). He also stresses the importance of tracking the vast range of constructions of indigenous religion by scholars, as well as adherents and advocates, through the colonial era into post-apartheid South Africa.

Furthermore, scholars and students of indigenous religions in Africa need to take a leaf out of this Chidester book and understand the capacity of these religions to transact, creatively and strategically, whether with colonial powers, traditional authority, the capitalist economy, or the modern state. Each example chosen by Chidester underscores the 'wild' and relational nature of these transactions and their entanglement in a changing world. In other words, 'indigenous religion is a wild religion, not because it is practiced by wild savages, but because it is engaged with modernity' (Chidester 2012:198). Drawing from the wellspring of his longitudinal, lived experience and knowledge of the South African religious and political scene, Chidester supplies some telling examples of attempts to block transactions in the interests of protecting one's own religious heritage. He cites the cases of evangelical Christians objecting to the inclusion of indigenous African religion in the new educational policy, Xhosa sangoma Dr. Nokuzola Mndende's campaign to prevent the initiation of white sangomas, and the debates over the dangers of pornography to Zulu maiden festivals, and extra-marital affairs and same-sex marriage to African tradition. Happily, in Chidester's estimation, many of these contestations were resolved during the 'ultimate festival' in South Africa that was the 2010 FIFA World Cup, with all its attendant religious ceremonies (Chidester 2012:206). However, some readers may be left wondering how indigenous religion advocates might find Chidester's overall emphasis on wildness, complexity, fluidity, and constructedness rather challenging to mobilize in more formal, legal contexts.

As someone currently engaged in tracking the transformations of indigenous religion in Nigeria and Uganda, Wild religion offers all sorts of critically important angles to think with, not least in terms of the permutations and entanglements of the sacred in rapidly changing political and urban contexts. Surely there are many other parts of Africa crying out for such 
analysis. How this bold, insightful, and playful work by one of our most influential colleagues in the field of (African) religious studies might usefully 'disrupt' my anthropology of religion class next spring is now uppermost in my mind.

\section{References}

Chidester, D. 1996. Savage systems: Colonialism and comparative religion in Southern Africa. Charlottesville: University of Virginia Press.

Chidester, D. 2002. Credo Mutwa, Zulu shaman: The invention and appropriation of indigenous authenticity in African folk religion. Journal for the Study of Religion 15, 2: 65-85.

Chidester, D. 2008. Zulu dreamscapes: Senses, media, and authentication in contemporary neo-shamanism. Material Religion: The Journal of Objects, Art and Belief 4, 2: 136-158.

Chidester, D. 2012. Wild religion: Tracking the sacred in South Africa. Berkeley, Los Angeles: University of California Press.

Comaroff, J.L. \& J. Comaroff 2009. Ethnicity, Inc. Chicago: University of Chicago Press.

Falen, D.J. 2018a. African vodun in the age of globalization. Anthropology News, 11 September 2018. Available at: http://www.anthropologynews.org/index.php/2018/09/11/african-vodun-in-the-age-ofglobalization/. (Accessed on 12 September 2018.)

Falen, D.J. 2018b. African science: Witchcraft, vodun, and healing in Southern Benin. Madison: University of Wisconsin Press.

Hackett, R.I.J. 2015. Traditional, African, religious, freedom? In Sullivan, W.F., E.S. Hurd, S. Mahmood \& P. Danchin (eds.): Politics of religious freedom. Chicago: University of Chicago Press.

Kara Heritage Institute. 2018. Welcome to the Kara Heritage Institute. Available at: http://www.kara.co.za/. (Accessed on 12 September 2018.) UiT. n.d. Indigenous religion(s) (INREL). The Arctic University of Norway. Available at: https://en.uit.no/forskning/forskningsgrupper/gruppe?p_ document_id=383890. (Accessed on 12 September 2018.)

Rosalind I.J. Hackett Department of Religious Studies 
Tracking the Indigenous Sacred, Chidester-style

University of Tennessee rhackett@utk.edu 